\title{
Status på internationalisering i læreruddannelsen
}

\section{Tove Heidemann, ph.d., tove.heidemann@gmail.com}

\begin{abstract}
Resumé
I denne artikel analyseres, hvilke muligheder for internationalisering den nye læreruddannelse rummer. Hvilke aktiviteter, der bliver realiseret, og hvilke problemer, der er forbundet med at gennemføre internationale aktiviteter. Undersøgelsen, som er den første af sin art, omfatter analyse af centrale dokumenter og en empirisk del bestående af en spørgeskemaundersøgelse besvaret af internationale koordinatorer på læreruddannelserne og referater fra møder mellem disse. De væsentligste konklusioner er, at der er færre studerende på studieophold i udlandet end under den forrige lov, men flere på praktikophold. Desuden er der stærkere internationale læringsmiljøer i form af nyudviklede specialiseringsmoduler.
\end{abstract}

\section{Nøgleord}

Internationalisering, studentermobilitet, medarbejdermobilitet, specialiseringsmoduler, projektsamarbejde.

Artikel uden for tema. Vejledt

\section{Indledning}

1. juni 2012 blev der indgået aftale mellem regeringen, Venstre, Konservative og Dansk Folkeparti om en ny læreruddannelse. Bekendtgørelsen trådte i kraft i sommeren 2013. Den nye læreruddannelse markerer på afgørende punkter et brud med de forrige. Det får betydning også for internationaliseringen. Forud var gået en omfattende monitorering. Da den forrige lov om læreruddannelsen blev vedtaget i 2006, blev der samtidig nedsat en gruppe, som løbende skulle følge udviklingen på området og overvåge lovens virkninger. Formålet var "at bistå forligskredsen bag læreruddannelsen i deres drøftelser af behovet for at foretage eventuelle justeringer af loven" (Følgegruppen for ny læreruddannelse, 2012, s. 4). Følgegruppens arbejde blev præsenteret i rapporten "Deregulering og internationalisering - evaluering og anbefalinger om læreruddannelsen af 2006" i januar 2012. Titlen på rapporten afspejler de 
væsentligste anker mod 2006loven. En af kilderne til rapporten var "Læreruddannelse med et internationalt perspektiv" fra 2008 udgivet af Rådet for Internationalisering/CIRIUS. Begge rapporter kritiserer 2006loven for alt for rigide vilkår for internationalisering.

Jeg har valgt af definere begrebet internationalisering som en ændringsproces, hvor ledere og medarbejdere indretter uddannelsen, således at man kan samarbejde med partnere i andre lande. Det sker gennem øget mobilitet af studerende og lærere, fælles udviklingsprojekter og inddragelse af internationale aspekter og perspektiver i undervisningen.

\section{Artiklens indhold og opbygning}

Der indledes med en sammenligning af 2006loven med 2013bekendtgørelsen (justeret i 2015). Samtidig med at loven om professionshøjskoler og den nye bekendtgørelse åbnede for nye muligheder, stillede regeringen nye krav og forventninger. Det skete gennem to strategier for internationalisering i 2013 og i 2014 og især gennem kravet om balance mellem udgående og indkommende mobilitet og gennem udviklingskontrakternes kvantitative mål, som vil blive præsenteret. Jeg har desuden gennemført en empirisk undersøgelse, som bygger på resultatet af en spørgeskemaundersøgelse gennemført i marts 2016, besvaret af de internationale koordinatorer på læreruddannelserne i Danmark og på i alt syv referater fra møder i Netværket af internationale koordinatorer på læreruddannelserne (LINK-møder) fra august 2012 og fremefter. I det afsluttende afsnit er de vigtigste resultater sammenfattet.

Jeg har arbejdet med at fremme internationalisering i uddannelserne siden slutningen af 1980'erne og er dermed ikke nogen uvildig forsker. Min ph.d. fra 1999 handler om internationalisering i skolen, og fra 2004 til 2015 var jeg "Head of international Relations" på University College Syddanmark. I mine øjne er læreruddannelsen den mest interessante af alle de videregående uddannelser. Hvis uddannelserne kan sikre, at de lærerstuderende får internationale erfaringer under studiet, vil det på længere sigt få gennemslag også i folkeskolen. Påstanden er, at mødet med det fremmede og samarbejdet med kolleger i andre lande ikke kun styrker læreres og studerendes interkulturelle kompetencer, men også bidrager til en øget faglig og pædagogisk kvalitet.

Sammenligning af 2006loven og 2013bekendtgørelsen m.h.t. muligheder for internationalisering 
Følgegruppens rapport slår fast, at "(lærer)uddannelsen $i$ dag uden sammenligning er den mest regelregulerede videregående uddannelse i Danmark" (Følgegruppen for ny læreruddannelse, 2012, s. 12). Bekendtgørelsen for læreruddannelsen fra 2006 fyldte 65 sider, hvor alle fags centrale kundskabs og færdighedsområder blev detaljeret beskrevet (BEK 219, 2007). Det var ikke tilladt at afvige herfra, f.eks. måtte der ikke oprettes fag eller dele af fag, som ikke var beskrevet i bekendtgørelsen. Hensigten var, at læreruddannelsen på nationalt plan skulle være ens og af høj faglig standard.

Uddannelsens opbygning indebar en progression, hvilket betød, at ét linjefag kunne strække sig over flere semestre. Fagene blev gennemført parallelt, således at den enkelte studerende kunne have tre eller fire pr. uge. Det gjorde det meget vanskeligt for studerende at få godskrevet et udenlandsophold, fordi det var urealistisk at antage, at man kunne finde det samme fagudbud på samme niveau på en udenlandsk læreruddannelse. Alligevel var det et krav, at uddannelsen skulle give de studerende mulighed for at tilbringe mindst tre måneder i udlandet og få opholdet godskrevet som en del af studiet (BEK 219, § 37, stk. 2). Enkelte læreruddannelser indgik faste aftaler med få, udvalgte partnere, hvilket betød, at de studerende fik tilbud om at rejse ud på bestemte semestre og deltage i på forhånd aftalte fagelementer, som kunne godskrives 1:1 i den hjemlige uddannelse. Det var tilladt at gennemføre praktik i udlandet, men kun tre ugers udlandspraktik kunne godkendes, og kun hvis det indgik i et studieophold (BEK 219. § 8, stk. 3). Under de vilkår var det forståeligt, at studentermobiliteten var lav, hvilket var en tilbagevendende klage på de internationale koordinatorers møder (LINKmøderne). Det var tilladt at udbyde fagene på engelsk, hvorved man kunne tiltrække udenlandske (Erasmus)studerende. Der måtte også gennemføres eksamen på engelsk identisk med den tilsvarende eksamen på dansk, men hver enkelt eksamen skulle på forhånd godkendes af Undervisningsministeriet (BEK 219, § 49, stk. 5). Eftersom de færreste Erasmus-studerende tilbragte et helt semester på læreruddannelsen og dermed ikke gik til eksamen, udløste deres ophold ikke økonomisk tilskud. De internationale koordinatorer på læreruddannelserne så derfor frem til, at der ville komme en ny lov med gunstigere vilkår.

Læreruddannelsen af 2013 viste sig at blive - ikke en justering - men et regulært paradigmeskifte (Følgegruppen for ny læreruddannelse, 2012, s. 62). Overordnet skete der et skifte fra regelregulering til udstrakt frihed både på individplan og institutionsplan. 
Princippet om ensartethed på landsplan blev forladt til fordel for en tilskyndelse til lokalt at udvikle særlige profiler. Disse profiler kan styrkes gennem specialiseringsmoduler/valgmoduler eller tværgående moduler, hvor den enkelte uddannelse kan udvikle og udbyde egne moduler. Modulerne kan udbydes på engelsk, således at udenlandske og danske studerende kan læse sammen. Der sker et skifte fra fokus på curriculum, udmøntet i CKF'erne, til fokus på de studerendes udbytte af uddannelsen udtrykt i centralt udformede kompetencemål. Intentionen om progression i fagene ændres til modulisering, som skal gøre det lettere for den enkelte studerende at opbygge sit eget uddannelsesforløb af byggeklodser, som kan hentes forskellige steder fra. Ikke kun fra udenlandsophold, men også fra moduler på andre danske læreruddannelser eller universiteter. Modulerne kan være på mellem 5 og 20 ECTS, men ikke "skæve", for så er de for vanskelige at bygge med. Det betyder, at det ikke længere er uddannelsens ansvar, at den studerende gennemgår det stof, der er nødvendigt for at bestå kompetencemålsprøverne, men den studerendes eget ansvar. I sin yderste konsekvens betyder det, at uddannelsesstedet blot skal anerkende et udenlandsophold som meritgivende, men ikke har hjemmel til at kræve, at undervisningen skal være præcis som den, , der bliver gennemført på egen institution. Nyt er også, at bachelorprojektet nu ikke længere skal være knyttet til et bestemt fag. Det betyder, at et studieophold eller et praktikophold i udlandet også kan bruges til at samle empiri til f.eks. et komparativt pædagogisk projekt.

Imidlertid står der meget lidt eksplicit om internationalisering i bekendtgørelsen. Om praktik hedder det (BEK 1068, § 12, stk. 3): "Praktikken [...] kan efter godkendelse af professionshøjskolen $i$ det enkelte tilfxlde finde sted $i$ udlandet, på Færøerne eller i Grønland". Desuden står der i § 24, stk. 2: "Studieordningens institutionsdel skal indeholde regler om følgende: Muligheden for deltagelse $i$ internationale aktiviteter, herunder studieophold og praktik $i$ udlandet, $i$ internationale udvekslingsprojekter og $i$ samarbejde med udenlandske studerende."

Hermed er det pålagt den enkelte læreruddannelse at beskrive, hvilke internationale aktiviteter man vil tilbyde de studerende. Med den nye læreruddannelse bliver kompetencemålene altafgørende for både undervisningens tilrettelæggelse og prøverne. Der står meget lidt konkret om indhold af relevans for en international dimension i de enkelte fag.

Læreruddannelserne reagerede forskelligt på den nye bekendtgørelse. Nogle valgte at implementere den med 2013-årgangen. Andre tog også 2012-årgangen med i form af en overgangsordning. Det betyder, at nogle læreruddannelser dimitterede de første bachelorer efter ny ordning i 
sommeren 2016. Nogle valgte at tilrettelægge praktikperioder af forskellige længder på mellem 5 og 15 ECTS. Andre opererer med 3 x 10 ECTS. Rammeplanerne er meget forskellige, hvilket er helt i lovens ånd, men hvilket unægtelig gør det vanskeligere at skabe overblik over praksis. Desuden fortolker læreruddannelserne merit for udenlandsophold mere eller mindre restriktivt, herom senere.

Positivt udtrykt rummer bekendtgørelsen gode rammevilkår for internationalisering. Men eftersom den hverken er detaljeret eller eksplicit, er meget overladt til den enkelte læreruddannelse og det enkelte UC at fortolke og implementere.

\section{Nationale strategier og krav}

I maj 2013 udsendte regeringen handlingsplanen "Øget indsigt gennem globalt udsyn - flere studerende på studieophold i udlandet, styrkede internationale læringsmiljøer og bedre fremmedsprogskompetencer". Strategien rettede sig mod alle videregående uddannelser. Udgående studentermobilitet har uden sammenligning den største politiske opmærksomhed. Det konstateres, at i den seneste mobilitetsstatistik fra 2011/12 (UFM, 2013) havde 17 $\%$ af alle danske studerende været på et studie eller praktikophold i udlandet i løbet af deres studier. Det betragtes som utilfredsstillende. Det hedder på s. 8: "I 2020 bør mindst $50 \%$ af dimittender fra de danske videregående uddannelsesinstitutioner have været på studie eller praktikophold $i$ udlandet". Denne forventning er langt mere ambitiøs end Bologna-aftalen, der populært omtales som 20/20: Ifølge den bør $20 \%$ af alle europæiske dimittender i 2020 have gennemført et studie eller praktikophold i udlandet.

Af mobilitetsstatistikken fremgår det endvidere (s 14.), at 27,9 \% af de studerende på universitetsuddannelser har været på udenlandsophold, men kun 7,6 \% af de studerende på professionshøjskoleuddannelser. Af dem i alt 1.549 personer (s. 13). Hvor mange af dem, der er lærerstuderende fremgår ikke af statistikken, fordi lærer og pædagogstuderende er slået sammen til i alt 844 personer. Imidlertid har pædagogstuderende altid haft særdeles gode muligheder for at afvikle deres praktikperioder i udlandet, hvorfor det må antages, at hovedparten af de nævnte er pædagogstuderende. Mobilitetsstatistikken medtager ikke kun ophold af over tre måneders varighed, som kan udløse Erasmus-stipendium, men også kortere ophold. Således har 35 \% af de studerende på professionshøjskoler været på ophold af under tre måneders varighed, fremgår det. Der er altså tale om meget usikre tal for lærerud- 
dannelsens vedkommende. Regeringens strategi medførte en diskussion af hvor kort et udenlandsophold, der kunne tælles med i statistikken. I december 2014 kom den endelige afgørelse i form af en skrivelse fra Uddannelses og Forskningsministeriet (UFM) til UC'ernes ledere: Udenlandsophold af over to ugers varighed kunne regnes med i indberetningen. UC'ernes egne forventninger til øget mobilitet fremgår af de udviklingskontrakter, som det enkelte UC indgår med UFM. Der ligger således et stærkt pres på UC'erne og dermed læreruddannelserne om at forøge den udgående studentermobilitet drastisk for at kunne leve op til de 50 \% i 2020.

Et andet incitament til at øge den udgående studentermobilitet er kravet om balance. De videregående uddannelser må ikke optage flere Erasmus-studerende, end de sender ud. Det er attraktivt for institutionerne at optage

Erasmus-studerende, fordi det udløser økonomiske tilskud som til danske studerende. Der har igennem flere år været langt flere indkommende studerende end udgående på de videregående uddannelser. Dette balancekrav blev i første omgang fremsat over for universiteterne og resulterede i, at de måtte tilbagebetale adskillige millioner til staten. Det var nemlig forskellen mellem den indtægt, de havde fået for indkommende Erasmus-studerende, og det langt mindre tab, de havde lidt ved at sende egne studerende ud. Balancen opgøres over en treårig periode på institutionsniveau og altså ikke pr. grunduddannelse. Der er således to forskellige indberetningssystemer. Det ene vedrører balancekravet og drejer sig om udvekslinger af minimum tre måneders varighed. Det andet vedrører kravet om udgående studentermobilitet, hvor alt over to uger tælles med.

\section{Stærkere internationale læringsmiljøer}

Den anden del af handlingsplanen vedrører internationale læringsmiljøer. Her kan internationale studerende hjælpe med til at skabe et mangfoldigt læringsmiljø. Det samme gælder samarbejde på tværs af landegrænser (Regeringen, 2013, s. 19). Desuden nævnes uddannelseseksport. Handleplanen ønsker især at fremme fællesuddannelser og parallelforløb ('Joint Degrees' og 'Double Degrees'). Desuden ønsker man at øge medarbejdermobiliteten, som i 2012 var på i alt 400 personer finansieret med Erasmus-stipendier. Det er alt for få, konstateres det, forstået på den måde at øremærkede Erasmus-midler til 'Staff Mobility' måtte sendes retur til Bruxelles.

Den anden handlingsplan, som udkom 9. april 2014, hedder "Danmark - et attraktivt uddannelsesland. Sådan tiltrækker og fastholder Danmark 
talenter fra udlandet" (Regeringen, 2014). Her er der stor vægt på, at de videregående uddannelser kan tiltrække studerende, som selv vil betale for deres uddannelse. Det skal studerende, der kommer fra lande uden for EU. Det forventes, at i 2020 skal mindst $20 \%$ af de internationale studerende være selvbetalende. Desuden skal det sikres, at færdiguddannede ikke rejser tilbage til hjemlandet, men får arbejde i Danmark. Den nuværende regering har ikke udarbejdet nye strategier for internationalisering, hvorfor de nævnte strategier fortsat anses for at være gældende.

\section{Den empiriske undersøgelse}

En ting er, hvad Regeringen har ønsket i 2013, noget andet, hvordan virkeligheden ser ud i 2016. Den seneste kvantitative undersøgelse af relevans for internationalisering på læreruddannelserne er Rambølls baseline fra 2015 (Rambøll, 2015). Den er blevet til på foranledning af Rektorkollegiet for Danske Professionshøjskoler, og den omfatter hele sektoren, der udgør en meget broget vifte af uddannelser med meget forskellige vilkår og motivation for internationalisering. Desuden er lærer og pædagoguddannelserne som vanligt slået sammen, hvilket gør det vanskeligere at anvende resultaterne i den foreliggende sammenhæng. Undersøgelsen konstaterer tidligt (Rambøll, 2015, s. 19), at mens aktiviteten er høj på de tekniske og designfaglige uddannelsesretninger, "... har velfxrdsuddannelserne en stærk orientering mod danske forhold og praksis".

Kortlægningen skal understøtte realiseringen af 2020-målene for studentermobilitet og internationalisering, som de er beskrevet $\mathrm{i}$ handlingsplanen fra 2013. Således undersøges både status på internationaliseringen og "paratheden". Det sker gennem eksplorative interviews med de internationale chefer, med en surveyundersøgelse blandt ledere og medarbejdere og med fokusgruppeinterviews af danske og udenlandske studerende. Rambøll har haft problemer med at udarbejde mobilitetsstatistik. Det fremgår, at indberetningerne har været forskellige, "... der er store variationer $i$ opgørelsesmetoder på tværs af institutionerne, og at der derfor er betydelige huller i datamaterialet" (Rambøll, 2015, s. 3).

En opgørelse omfatter en procentvis angivelse af studerende dimitteret $\mathrm{i}$ 2013, der har været på et udenlandsophold af mindst 14 dages varighed.

Danmarks Medie og Journalisthøjskole ligger i top med $34 \%$, UC Lillebælt, VIA og UC Sjælland har haft henholdsvis 6,6 og 7 \% ude. De øvrige har lidt over $10 \%$. Der synes at være langt både til Bologna-aftalens $20 \%$ 
og regeringens forventning om 50 \% i 2020. Det lægger Rambøll-rapporten da heller ikke skjul på. "De politiske målsætninger for internationaliseringen af danske uddannelser er meget ambitiøse" (Rambøll, 2015, s. 5). Og i anbefalingerne: "Der er derfor et stort behov for en dialog med det politiske niveau om at skabe mere differentierede internationaliseringsmålsætninger, der er afstemt efter uddannelsernes struktur og faglige indhold". (s. 58) Rambøll-rapporten forholder sig således kritisk til de politiske forventninger om øget mobilitet.

Ligesom Rambøll-undersøgelsen er denne en 'stateofthe-art', der tilstræber at tilvejebringe et øjebliksbillede af internationale aktiviteter på læreruddannelserne i foråret 2016. Det er så vidt vides første gang, en sådan national empirisk undersøgelse af internationalisering på alle læreruddannelser er blevet gennemført. Undersøgelsens informanter er de internationale koordinatorer på uddannelserne, som især varetager ind og udgående mobilitet. Datagrundlaget består af i alt syv referater fra LINKnetværket (fra august 2012, hvor konturerne af den nye læreruddannelse begyndte at tegne sig, til det seneste i marts 2016). Jeg har selv deltaget i alle møder. Den anden kilde er et spørgeskema, som er blevet besvaret af koordinatorer fra alle UC'er samt fra Den frie Lærerskole. Spørgeskemaet blev præsenteret i kladdeform på LINKmødet i Århus i marts og umiddelbart herefter udsendt til alle koordinatorer. Der kom i alt 10 besvarelser tilbage, hvoraf nogle dækkede mere end én læreruddannelse. Spørgsmålene drejede sig udelukkende om konkrete internationale aktiviteter. De blev valgt på baggrund af et forudgående kendskab fra møderne til, hvilke aktiviteter der var blevet realiseret. Der er altså ikke blevet spurgt om noget, som ikke på mindst én læreruddannelse har været gennemført eller planlagt.

Spørgeskemaet er udsendt $\mathrm{i}$ et simpelt Wordformat og består af to dele. De første spørgsmål vedrører indgående og udgående studenter og medarbejdermobilitet i skoleåret 2014/15 og kan besvares kvantitativt. Den anden del vedrører moduler, internationale linjer og projektsamarbejde både i et aktuelt og et fremadrettet perspektiv. Der er desuden efterfølgende telefonisk indhentet ekstra oplysninger fra koordinatorerne, blandt andet for at opklare misforståelser. Optællingen af svar er sket manuelt ved simpel sammentælling for hvert enkelt spørgsmål. Da det viste sig, at mobilitet og aktivitetsniveau generelt var lavt, har jeg valgt at holde registreringen delvist anonym. Der er ikke nogen uddannelse, der skal føle sig hængt ud for pauvre resultater. Dog har jeg angivet, hvem der har de høje tal. De kan skyldes UC'ets størrelse, men de kan også skyldes en særlig satsning og kan derfor være interessante til inspiration for andre. Alle koordinatorer har til 
opgave at fremme den udgående studentermobilitet. Hvad de derudover arbejder med, kan øjensynligt være forskelligt. Det viste sig nemlig, at flere af koordinatorerne ikke kunne besvare alle spørgsmål. Det er i optællingen markeret med "ikkeregistreret". Som i Rambøll-undersøgelsen er der derfor "huller i datamaterialet".

\section{Resultaterne af spørgeskemaundersøgelsen}

I den følgende optælling er de aktiviteter, der er blevet spurgt om, markeret med fede typer. Til hver aktivitet er knyttet forklarende kommentarer. Det første spørgsmål drejede sig om studieophold af min. tre måneders varighed i 2014/15. De internationale koordinatorer har oplyst det konkrete antal studerende, som de jo selv har sendt ud. Det ser således ud:

\section{Udgående studentermobilitet}

Studieophold af minimum tre måneders varighed: $0,0,2,5,5,6,7,7,32$ (alle fire læreruddannelser i VIA) og 36 (begge læreruddannelser i UCC) Ifølge UniC's opgørelse var der 30.9.2014 indskrevet i alt 11.616 studerende på danske læreruddannelser (Minus Den frie Lærerskole). Med det antal in mente må sammenlagt 100 danske lærerstuderende på tre måneders studentermobilitet anses for at være lavt. Ifølge de internationale koordinatorer er det lavere end under den sidste lov.

Praktikophold: 0, 3, 4, 5, 10, 20, 22, 22, 51 (Metropol), 51 (UCN), 67 (VIA). For nogle studerende indgår der et praktikophold i studieopholdet. Derfor kan tallene være usikre. Nogle studerende kan være blevet talt med både under studieophold og praktikophold. Ifølge bekendtgørelsen (BEK 1068, 2015) kan et praktikophold være mellem 5 og 15 ECTS. Det vil sige, at et rent praktikophold maximalt kan vare to måneder. Så langt et ophold er til fordel for de studerende, fordi de kan få Erasmus+-stipendium til praktik af 15 ECTS's omfang. PÅ UCN skal alle studerende, der vælger international linje, i obligatorisk praktik i udlandet. Det er med til at forklare det høje antal i Nordjylland.

Antallet af studerende på praktikophold har været stærkt stigende med den nye læreruddannelse ifølge de internationale koordinatorer. 
Tove Heidemann: Status på internationalisering i læreruddannelsen

Udgående studentermobilitet på to ugers varighed eller derover: (ikke registreret), (ikke registreret), (ikke registreret) 2, 14, 22, 27, 33, 53 (UCN), 99 (VIA)

UCN's høje antal skyldes, at læreruddannelsen tilbyder to ugers mobilitetspakker i alle fag. Dette er minimumsperioden for registrering af mobilitet i henhold til udviklingskontrakten. Læreruddannelserne har derudover en lang tradition for studierejser i fagene, men de er som oftest på under en uges varighed og tæller således ikke med.

\section{Indkommende studentermobilitet}

Studerende på Erasmus-ophold: 0, 0, 0, 0, 0, 8, 25, 32 (Haderslev), 38 (Odense), 73 (UCC)

Et Erasmus-ophold er på minimum tre måneder, svarende til 20 ECTS. For at tiltrække Erasmus-studerende skal man altså kunne tilbyde engelsksprogede moduler på i alt 30 ECTS i løbet af et semester.

Studerende på praktikophold: $0,0,0,0,0,0,1,1,9,10$

Der er langt færre udenlandske studerende i praktik på danske skoler end omvendt. Det har til dels sproglige årsager, men der er heller ikke noget incitament for læreruddannelserne til at tilbyde det. I Danmark betaler læreruddannelsen skolerne for at have praktikanter, og det skal de også gøre, når det drejer sig om udlændinge.

Som det fremgår af handleplanen fra 2014 (Regeringen, 2014), ønsker regeringen at tiltrække og fastholde udenlandske studerende. Indtil videre har kun få læreruddannelser internationale studerende på hele uddannelsen.

\section{'Fulltime' studerende: 0, 0, 0, 0, 1, 3, 16 (Vordingborg), 29 (Haderslev)}

For at have 'fulltime' studerende kræver det, at man kan tilbyde en fire års uddannelse for udlændinge. Det kan Vordingborg og Haderslev. De tilbyder hver deres model.

Vordingborg har en 'joint degree' i samarbejde med et norsk og et hollandsk universitet. Dermed lever Vordingborg, som den eneste danske læreruddannelse, op til regeringens ønske om 'joint degrees' og 'double degrees'. De danske studerende, der vælger "International Talentlinje", skal læse mindst tre moduler på dansk, men kan læse de øvrige på engelsk. Desuden er et studieophold eller et praktikophold i udlandet obligatorisk. De får en særlig udmærkelse på deres eksamensbevis - en 'honor's degree'. Uddan- 
nelsen er blevet udviklet gennem et flerårigt pilotprojekt finansieret af det daværende LifeLongLearning-progam.

Haderslevmodellen blev oprettet i 2008 med dispensation fra Undervisningsministeriet til at optage udenlandske studerende, oprindeligt fortrinsvis fra Nordtyskland. De udenlandske studerende starter med enten engelsk eller tysk som første fag og lærer i løbet af det første år så meget dansk, at de kan følge resten af uddannelsen på dansk og blive lærer i en dansk folkeskole. Det er altså ikke en international linje, men en indslusningsmodel.

Også 'summer schools' er højtprioriterede i handlingsplanen om et attraktivt uddannelsesland. Men det kan heller ikke siges at være blevet nogen succes på læreruddannelserne.

UCN tilbød i 2014 'summer school' om nordisk pædagogik. Den blev ikke oprettet på grund af for få tilmeldinger og vil ikke blive udbudt igen. VIA tilbyder summer school om sport og svømning. UC Syd tilbyder i 2016 summer school med titlen "The Freedom Writers Way - a practical way to deal with at risk children and young people". Den retter sig mod lærerstuderende og socialrådgiverstuderende. Kurset blev også udbudt i 2015, men samlede ikke et tilstrækkeligt antal tilmeldinger. En af begrundelserne for den manglende tilmelding kan være, at det er dyrt for de studerende at deltage i en 'summer school'. Udenlandske deltagere skal betale både rejse, ophold og undervisning.

Haderslev tilbyder et andet koncept udviklet i et netværk af europæiske læreruddannelser. 1617 af disse uddannelser tilbyder hvert år en 'International week' til studerende fra partnerinstitutionerne. Den kan fungere som en appetitvækker for efterfølgende Erasmus-ophold. I 2015 var der 28 udenlandske studerende på en uges ophold i Haderslev. Esbjerg og Haderslev har således 3234 pladser på ugekurser i andre lande. De studerende betaler rejse og ophold, værtsinstitutionen betaler for undervisning. Interessen for at rejse ud er imidlertid behersket fra de danske studerendes side.

\section{Udgående medarbejdermobilitet}

Medarbejdermobilitet er et højt prioriteret område i handlingsplanen fra 2013 (Regeringen, 2013). Det udbygger undervisernes faglige og sproglige kompetencer, hedder det. Samtidig kan underviserne inspirere de studerende til selv at tage ud ved at synliggøre de positive faglige input, som kan opnås gennem et udlandsophold. Det fremgår (s. 20), at antallet af udgående medarbejdermobilitet med Erasmus-stipendium har ligget stabilt på 300350 
om året, men som i 2012 dog var steget til 400. Tallet omfattede samtlige videregående uddannelser.

Erasmus gæstelærer: (ikke registreret) 0, 1, 3, 4, 4, 4, 6, ca. 10 (VIA)

\section{Erasmus Training: (ikke registreret) (ikke registreret) (ikke registreret)} (ikke registreret) $0,1,2,4$

Som det fremgår, er antallet udrejsende medarbejdere med Erasmus-stipendium lavt. Det kan der være flere grunde til. Erasmus-mobilitetsmidlerne går til den centrale internationale enhed på UC'erne, som fordeler dem på uddannelserne. Der kan være overordnede strategiske overvejelser, som bestemmer hvilke uddannelser, der skal tilgodeses. Det er en udgift for uddannelserne, fordi det kan koste timer at sende en medarbejder ud. Det kan også være vanskeligt at motivere underviserne til at rejse ud, fordi de har rigeligt at lave i forvejen. Nogle koordinatorer melder også om, at deres kolleger finder det hårdt at rejse og undervise på et fremmedsprog på egen hånd. På VIA anvendes Erasmus-stipendierne strategisk. De bruges til at besøge praktikskoler i Europa og sikre kvaliteten. Besøg på praktikskoler uden for Europa betales af VIA selv. Der er udpeget ca. 15 undervisere, som har denne opgave. Tidligere, da der var mange internationale projektsamarbejder, brugte nogle UC'erne medarbejderstipendier til at sende ekstra undervisere med til projektmøder og 'Erasmus Intensive Programmes'. Der var almindelig enighed om, at et samarbejde er for skrøbeligt, hvis det kun hviler på en enkelt lærer.

\section{Indkommende medarbejdermobilitet}

Erasmus gæstelærer: (ikke registreret), (ikke registreret), (ikke registreret), 0, 4, 5, 6, 7, 12 (Haderslev)

Erasmus Training: (ikke registreret), (ikke registreret), 0, 0, 0, 0, 1, 2, 4

\section{International staff week:}

UCC har haft en 'international staff week' i 14/15 med 18 gæster. Til 'staff week' i 2016 er der tilmeldt i alt 50 gæster, heraf 30 fra udenlandske læreruddannelser. UC Syd tilbyder første gang en international 'staff week' i april 2016 med ca. 20 gæster fra flere uddannelser. Fordelen ved at tilbyde en 'staff week' er, at man dermed kan opsuge en del af de udenlandske gæster, som 
ellers ville komme individuelt i løbet af året. Det er et stort arbejde at tilrettelægge op til en uges program for en enkelt person.

\section{Andre aktiviteter, der styrker internationaliseringen}

Mens spørgsmålene om mobilitet vedrørte skoleåret 2014/15, kunne de følgende spørgsmål bl.a. om internationale læringsmiljøer besvares både i et aktuelt og i et fremadrettet perspektiv. Der skal mindst tre moduler til for at udgøre et Erasmus-ophold på 30 ECTS. Nogle af dem kan være moduler i faget engelsk, andre engelsksprogede udgaver af moduler fra den danske læreruddannelse. Men adskillige af dem er "nye" i den forstand, at de er særligt udviklede til internationale studerende, samtidig med at danske studerende også kan vælge dem som specialiseringsmoduler eller tværfaglige moduler.

\section{Moduler på engelsk: 0, 0, 1, 3, 3, 5, 4, 7 (UCC), 10 (UCSJ), 10 (UCN)}

\section{Eksempler:}

- VIA: Internationalization and entrepreneurship in the Danish primary and lowersecondary school; Danish Dynamite (physical education); Math in Art.

- Metropol: Outdoor education, Innovation and Visual Culture.

- UCC: The Nordic Model; Innovation Lab; Didactics of Dialogue and Reconciliation.

\section{Tværfaglige moduler på dansk om internationalisering/interkulturel kompetence/komparativ pædagogik:}

- Vordingborg: Skolen i internationalt perspektiv. Sammenlignende studier: pædagogiske strategier, skole og barnesyn og forældre og læreridentitet i udvalgte lande og regioner. Studietur.

- VIA 1: Internationalt modul. Grundlæggende kulturbegreber og kulturforståelse, den internationale dimension i skolen i alle fag. Forberedelse, gennemførelse og efterbehandling af udenlandsophold.

- VIA 2: Åben skole og medborgerskab - lokalt og internationalt. Modulet gennemføres parallelt med tilsvarende på læreruddannelsen i Bergen, Norge og Nottingham Trent University, England. De studerende besøger hinanden i to uger og tilrettelægger og gennemfører sammen én dags "åben skole"aktiviteter. 
- VIA 3: Tanzania: Project development in and educational and different context in Tanzania (dansk/engelsk). Forstå skolen som institution i forskellige nationale og globale sammenhænge. Komparative studier mellem skoler og uddannelsesinstitutioner i Danmark og Kenya. Kulturforståelse og kulturmøder. Feltarbejde.

- Esbjerg: Undervisning om interkulturelle kompetencer. Styrke de studerendes kompetencer i at undervise om interkulturel forståelse, demokratisk dannelse og skolekultur i andre lande. Inklusive to ugers studietur i udlandet.

- Haderslev: Internationalisering $i$ skolen. Målgruppe: kommende internationale koordinatorer: Uddannelsespolitik. Den internationale dimension i undervisningen og organisationsudvikling.

- UCN: Under udvikling.

- DFL: Internationale kurser oprettes i 2017.

Som det fremgår, har flere af de internationale moduler en struktur, som betyder, at de studerende kommer ud på tougers ophold. Både tværfaglige moduler og specialiseringsmoduler og moduler på dansk ud over de obligatoriske er nye i den forstand, at de ikke kunne oprettes under den tidligere lov, som var meget restriktiv m.h.t. undervisningens indhold. De giver mulighed for at profilere uddannelserne og også for at tiltrække udenlandske studerende til fagområder, som de ellers ikke ville kunne få udenlandske studerende til.

Vordingborg og UCN har en international linje for danske studerende. Metropol har netop udbudt én.

\section{Bachelorprojektet}

Som tidligere nævnt er det i den nye læreruddannelse ikke længere et krav, at bachelorprojektet skal have tilknytning til et fag. Det åbner nye muligheder for at inddrage internationale perspektiver i opgaven. De studerende kan direkte udnytte deres erfaringer fra et studie eller praktikophold i udlandet til en komparativ undersøgelse eller til en opgave om internationalt skolesamarbejde. Imidlertid er der kun få læreruddannelser, der har implementeret den nye lov på alle årgange. Der hvor studerende kan skrive bacheloropgave efter ny lov, har det allerede vist sig, at der er langt flere opgaver om generelle eller tværfaglige pædagogiske problemstillinger end om faglige. 


\section{Internationalt projektsamarbejde}

Sammenlignet med tidligere år er der i dag meget få internationale projektsamarbejder. Her følger en nogenlunde dækkende oversigt:

Erasmus + Strategiske partnerskaber:

- Esbjerg: Early Childhood Education (samarb. pæd/lærer) Tyrkisk ledet projekt.

- UCL: Using Schools for Developing European Citizenship. Tyrkisk ledet projekt.

- UCN har søgt om et Strategisk partnerskab i 2015, men fik afslag. Søger igen i 2016.

- UCS har i 2016 søgt om et Strategisk partnerskab om skoleovertagelse.

\section{Nordplus:}

To på VIA, to på UCC, en på UC Syd. UCL er nordisk koordinator på et mangeårigt projekt om inklusion med i alt 14 partnere, heriblandt UC Syd og VIA.

\section{Andre samarbejdsprogrammer:}

- UCN Biophilia Educational project. Et nordisk samarbejde om naturvidenskab og musik.

- Haderslev har i 2015/16 et nordiskrussisk projekt finansieret af Nordisk Ministerråd.

- UCL har projektet GLAD i et samarbejde med Kenya. Det er støttet af DANIDA.

Så vidt vides, er det kun læreruddannelsen på Metropol som har haft indtægtsdækket konsulentvirksomhed i udlandet i et konsortiesamarbejde med Odsherreds Efterskole, Stenhus Kostskole og Gymnasiet i Holbæk. De har udarbejdet undervisningsmaterialer og -forløb og gennemført workshops på elitegymnasiet Datong High School i Shanghai. I lov om professionshøjskoler ekspliciteres ellers, at professionshøjskolerne må udbyde videregående uddannelser og efter og videreuddannelse $i$ andre lande (LBK 936, § 10a). Det kunne være en udbytterig international aktivitet for læreruddannelserne. Det er meget vel tænkeligt, at medarbejdere på læreruddannelserne er involveret i flere internationale projekter eller i konsulentvirksomhed. Men de kan organisatorisk være placeret i Forsknings og Udviklingsafdelingen eller et særligt projektkontor og bliver derfor ikke registreret af den internationale koordinator på læreruddannelsen. 


\section{Sammenfatning}

De indledende spørgsmål lød: Hvilke muligheder rummer den nye læreruddannelse? Hvilke aktiviteter bliver realiseret? Hvilke problemer er der forbundet med at realisere dem?

Som det fremgår af sammenligningen mellem 2006-loven og 2013-Bekendtgørelsen, er der langt flere muligheder for internationale aktiviteter under den nye læreruddannelse. Uddannelsen er blevet opdelt i moduler, hvilket skulle fremme både den udgående og den indkommende studentermobilitet. Det er blevet muligt at gennemføre hele praktikperioder i udlandet. Læreruddannelserne har fået mulighed for at udvikle egne moduler både på engelsk og dansk, som kan fremme internationalisering og udvikling af internationale kompetencer. Bachelorprojektet skal ikke længere være knyttet til et fag, men kan handle om skolens praksis i bredeste forstand. Regeringens strategi fra 2013 og UC'ernes udviklingskontrakter med UFM lægger et pres på alle uddannelser, herunder læreruddannelserne, om radikalt at forøge den udgående studentermobilitet.

Og hvad er der så sket? Det interessante er, at de danske læreruddannelser har udviklet forskellige internationale profiler og prioriteringer. VIA satser stærkt på praktik i udlandet, også uden for EU, og har udpeget et korps af lærere til at rejse ud for at kvalitetssikre skolerne. UCC har også under den tidligere lov haft mobilitetsvinduer med faste partnere, hvilket øger studentermobiliteten. UCN, Metropol og UC Sj/Vordingborg tilbyder særlige internationale linjer for danske studerende sammen med Erasmus-studerende. UCN har udviklet tougers mobilitetspakker i alle fag, så det bliver vanskeligt for de studerende at undgå at rejse ud. UC Syd har altid haft en tradition for europæisk projektsamarbejde. UCL har projektsamarbejde med udviklingslande.

Men det er generelt på tværs af uddannelserne, at den udgående mobilitet ift. studieophold er gået ned ifølge de internationale koordinatorer.

Under den tidligere lov var udfordringen, at fagene var så detaljeret beskrevet, at det var vanskeligt at planlægge et ophold og indgå en såkaldt 'learning agreement', som dækkede de elementer af fagene, som de studerende mistede. Det var en tilbagevendende klage på møderne for de internationale koordinatorer, at reglerne var så rigide. De studerende skulle tilbage og eksamineres i centralt stillede prøver, hed det i referatet fra 30.8.2012. To år senere (21.10.2014) konstateres det, at antallet af studieophold er lavere end under den gamle lov! Der er enighed om (referatet 27.8.2015), at med 
moduliseringen er det blevet nemmere at tiltrække udenlandske studerende - og sværere at få egne studerende ud. Kravene til merit er ikke klare, "de studerende skal opfylde kompetencemålene og tage eksamen hjemme". "De studerende tænker meget firkantet i forhold til kompetencebeskrivelser". På mødet 27.8.2015 udtrykkes der "en generel frustration over læreruddannelsernes reguleringer". Desuden konstateres det, at der synes at være forskellig praksis på UC'erne, både m.h.t. hvem der anerkender et udenlandsophold, og hvordan det godskrives. VIA synes at være mest large m.h.t. at give merit. Læreruddannelserne er blevet "genregulerede". Denne gang ikke af en bekendtgørelse, men af uddannelserne selv. Jeg antager, at det må være sket som følge af en form for inerti eller sædvanepraksis, for der står ikke noget i den fælles studieordning, som kan forklare, hvorfor der skal så mange reguleringer til, at mobiliteten vanskeliggøres. Noget tyder på, at forståelsen af paradigmeskiftet i læreruddannelsen endnu ikke er slået igennem. De studerende skal ikke prøves i, hvad de har været igennem, men hvad de kan. Hvordan de har lært det, er i princippet uddannelsen uvedekommende. Desuden er de studerende selv meget usikre med hensyn til, om de vil kunne bestå deleksaminerne, oplyser koordinatorerne.

Antallet af internationale projekter er gået væsentligt ned. Tilfældigvis kom implementeringen af den nye læreruddannelse til tidsmæssigt at falde sammen med at EU-Kommissionen afsluttede Lifelong Learning Programme og 1. januar 2014 i stedet påbegyndte et nyt seksårigt program med den overordnede titel Erasmus+. Det betød en drastisk nedgang i antallet af internationale projekter på læreruddannelserne. Siden 1996 havde uddannelsesinstitutioner kunnet søge om såkaldte 'Intensive Programmes' (IP's). Det var tilskud til tougers kurser for studerende og lærere fra flere forskellige lande. Tilskuddet dækkede rejser og ophold for studerende og lærere, arbejdstiden skulle dækkes af de deltagende institutioner ud fra den betragtning, at der var tale om forlagt undervisning.

Programmet blev en kolossal succes netop på læreruddannelserne i EUlandene. Det var relativt ubureaukratisk, det faglige og pædagogiske udbytte var i almindelighed stort, og det skabte et netværk af undervisere inden for det samme fagområde. Det betød, at det var overkommeligt også for de små, ofte monofaglige institutioner at deltage i eller koordinere. Programmet blev nedlagt i 2013 med den begrundelse, at det var for administrativt omkostningstungt for kommissionen. Det samme gjaldt de større Comenius Multilateral-projekter under LLP-programmet. Afløseren blev Erasmus + Strategiske Partnerskaber. Det er meget store projekter på minimum 300.000 
euro. Det er teknisk vanskeligt at skrive ansøgninger og budgetter, og det er et stort ansvar efterfølgende at være projektleder og økonomisk ansvarlig. Til gengæld er der heller ikke mange projekter, der bliver bevilget. I Danmark to i 2014 og to i 2015 på de videregående uddannelser. Ingen af dem på professionshøjskoler. Med mindre en læreruddannelse bliver inviteret med som partner i et udenlandsk ledet strategisk partnerskab, har internationale projekter i EU regi lange udsigter på læreruddannelserne. Derimod kan Nordplus-programmet to år i træk melde om et rekordstort antal ansøgninger, især fra de videregående uddannelser.

Det er der ikke noget at sige til, når projektmulighederne i EUregi tørrer ud.

\section{Afsluttende anbefalinger}

I lighed med Rambøll-rapporten, kan denne undersøgelse konkludere, at Regeringen i handlingsplanerne fra 2013 og 2014 har opstillet alt for ambitiøse mål for læreruddannelsernes vedkommende. Det gælder både den udgående studentermobilitet og forventningerne til 'summer schools', 'joint' og 'double degrees' og konsulentvirksomhed i udlandet.

Bekendtgørelsen fra 2015 rummer gode rammevilkår for internationalisering, men hvordan de udmøntes i praksis, afhænger af ledelsens prioriteringer. Der er ingen eksempler på, at internationalisering kan udvikles uden opbakning fra ledelsen. Derimod er der eksempler på, at manglende ledelsesopbakning kan få et eksisterende internationalt arbejde til at gå i stå. Mangeårige LINK-medlemmer kan bekræfte, at nogle læreruddannelser har haft et svingende aktivitetsniveau afhængig af ledelsesopbakningen og den internationale koordinators gennemslagskraft. Kun få uddannelser har haft en stabil internationalisering over en længere årrække. Hvis man ønsker at fremme udgående studentermobilitet skal uddannelsens struktur tilrettelægges, så den gør det muligt. Det er UCN et godt eksempel på med sine to ugers mobilitetspakker i alle fag. Det samme gælder UCC med sine mobilitetsvinduer. En effektiv løsning ville være at afsætte et semester til studie eller praktikophold i udlandet. Et sådant forslag har tidligere været fremsat. 
Tove Heidemann: Status på internationalisering i læreruddannelsen

\section{Referencer}

BEK 219 (2007). Bekendtgørelse om uddannelse til professionsbachelor som lærer i folkeskolen. Uddannelses- og Forskningsministeriet.

BEK 1068 (2015). Bekendtgørelse om uddannelse til professionsbachelor som lærer i folkeskolen. Uddannelses- og Forskningsministeriet.

LBK 936 (25. aug. 2014). Lov om professionshøjskoler for videregående uddannelser.

Rambøll (2015). Rapport om baseline 2015 for internationalisering i professionshøjskolesektoren.

Følgegruppen for ny læreruddannelse (januar 2012). Deregulering og internationalisering - evaluering og anbefalinger om læreruddannelsen af 2006. Lokaliseret d. 20. august 2016 på http://ufm.dk/publikationer/2012/deregulering-og-internationalisering-evaluering-og-anbefalinger-om-laereruddannelsen-af-2006

Uddannelses og Forskningsministeriet (2013). Mobilitetsstatistik for de videregående uddannelser 2011/12.

Regeringen (2013). Øget indsigt gennem globalt udsyn - flere studerende på studieophold $i$ udlandet, styrkede internationale læringsmiljøer og bedre fremmedsprogskompetencer. Uddannelses og Forskningsministeriet.

Regeringen (2014). Danmark - et attraktivt uddannelsesland. Sådan tiltrækker og fastholder Danmark talenter fra udlandet. Uddannelses og Forskningsministeriet. 